\title{
Exploring Values in the Sociopreneurship Course in Fostering Entrepreneurial Spirits in Social Science Education Students
}

\author{
Tetep $^{1, *}$ Jamilah $^{2}$, Ade Suherman ${ }^{3,}$ Yuyun Susanti ${ }^{4}$
}

\author{
${ }^{1}$ Institut Pendidikan Indonesia \\ ${ }^{2}$ Institut Pendidikan Indonesia \\ ${ }^{3}$ Institut Pendidikan Indonesia \\ ${ }^{4}$ Universitas Galuh \\ *Corresponding author.Email: tetep@institutpendidikan.ac.id
}

\begin{abstract}
The research aims to foster the entrepreneurial spirit of the students majoring in social science education at Institut Pendidikan Indonesia Garut using the Lecture Program Unit (SAP) developed for a sociopreneurship course. A classroom action research was carried out in two cycles consisting of the following activities: planning the action, carrying out the action, observation, and reflection. Data were collected using observation, questionnaire, and documentation. Data were analyzed descriptively. The results showed that the sociopreneurship course succeeded in fostering an entrepreneurial spirit in social science education students at the Garut Indonesian Institute of Education. Several important values were established; Creativity, innovative abilities, willingness to risk, good business ethics and norms, responsibility, and self-discipline. This increase is included in the medium category.
\end{abstract}

Keywords: Learning Values, Sociopreneurship, Entrepreneurial Spirits.

\section{INTRODUCTION}

Free trade and globalization have changed the world in social, economic, political and cultural developments. People who cannot adapt in the changing become dissociated from their social context. Humans have the intellectual competence and social skills to adapt to the technological era. Some people are very vulnerable in policy changing. The conditions may lead to low welfare and increase poverty rates. The infrastructure gap between rural and urban areas has resulted in uncontrolled urbanization [1]. The number of unemployments in Indonesia in August 2019 has increased from 7 million in August 2018 to 7.05 million, but they have decreased in percentage from $5.34 \%$ to $5.28 \%$. As for February 2019, the unemployment rate reached $5.01 \%$ or 6.82 million people. The total workforce in August 2019 was recorded at 197.92 million people, an increase compared to the same period in the previous year of 194.78 million. The work of participation rate increased from $66.67 \%$ in August 2018 to $67.49 \%$. The open unemployment rate was recorded to have decreased from 5.34\% in August 2018 to 5.28\% in
August 2019. The highest unemployment rate still comes from SMK graduates, but the trend is starting to decline [2]. Furthermore, The Indonesian Statistics recorded that the number of university graduates working as of August 2019 reached 12.27 people. This figure is 9.7 percent of the total workforce of 133 million people [3]. This figure is still far below the HDI growth target. A country can be said to be prosperous if the population becomes entrepreneurs at least 2\% [4], then at least Indonesia needs 5.34 million entrepreneurs to become a developed country. The results of interview is known that means to foster an entrepreneurial spirit Economics education students. It is also seen from some of the students who have been doing entrepreneurial activity [5].

Constraints that are in the entrepreneurship course to develop entrepreneurial spirit. Firstly, there is still little enthusiasm of students about the importance entrepreneurship courses. Secondly, they are still in direct practice in the course entrepreneurship. Thirdly, the are difficulties in starting entrepreneurship for students. In addition, there are some steps in conducting the entrepreneurship courses to develop souls 
entrepreneur, such as supporting and directing to put into practice the learning theory in real context [6]. Futhermore, the role of socio-economic background, family economics education and financial literacy influence the in decision making [7].

The Social Science Education Program at Institut Pendidikan Indonesia Garut offers a sociopreneurship program aiming to equip students with sociopreneurship skills in addition to teaching skills [8]. Currently, teacher welfare is difficult to achieve because there are several requirements that have to be embed, such as linearity, education and teacher certification. Teachers can be said not to be satisfied if their welfare has not been improved. Teacher satisfaction includes personal, social, economic and cultural satisfaction [9] Ideas and innovations are currently needed to improve social welfare [10]. Sociopreneurship is a noble activity. It is contrast if it compares to traditional entrepreneurship which only focuses on material benefits and customer satisfaction. In addition, the sociopreneurship has a significant contribution to social life. The concept of sociopreneurship has reached its peak in 2006 when Mohammad Yunus won the Nobel Prize for his work in the field of microeconomics for women in Bangladesh. It becomes a recognition and appreciation for a social entrepreneur [11]. However, it turns out that the social business performer also takes advantage of empowering people to do business. It cannot necessarily be bad because what they are doing must be sustainable.

Social entrepreneurship is commonly referred to as community development [12]. It contains of social care, social responsibility, honesty and discipline.Then, those characteristics are summarized in character education. Therefore, to produce a sociopreneuer, it needs an innovative learning method by combining an understanding of moral values and social entrepreneurship understanding. Education plays an important role in changing mindset and behavior patterns [13]. Universities have an essential role to instigate their students' entrepreneurial motivation which will eventually lead them to become job creators [7]. Thus, there are many social business performer that arise. Not only do they do the business to fill their daily needs, but they also contribute to the development of the economy. Then, it becomes the common goal of the Indonesian people and the government in increasing national income [14].

Social entrepreneurship refers to entrepreneurship for the benefit of society, not just maximizing personal gain [14]. The social entrepreneurship tries to solve the root of the problem, not just overcoming the ends of the problem in a systemic and sustainable way in the form of non-profit organizations, hybrids (a combination of profit and non-profit), people's banks, work training centers [15]. Innovations are created to address the root of the problem while social missions are developed in the fields of education, health, economics, and arts [12]. Forms of social entrepreneurship include: 1) Community-based organization which is usually created to solve certain problems in the community, 2) socially responsible enterprises which carry out commercial businesses to support their social enterprises, 3) socio-economic or dualistic enterprises which run their business based on social principles

The solution that is able to overcome the problem to increase the entrepreneurship of every individual is the developing of development of social entrepreneurship, especially youth as the backbone of the nation. Social entrepreneurship is expected to generate new business ideas which in turn have an impact reduce unemployment and poverty [16].

Reference [17] was stated Social entrepreneurship can be defined as the creation of a social value that is produced in collaboration with people and organization from the civil societies who are engaged in social innovations that usually imply an economic activity.

Reference [18] was described six characteristics values in entrepreneurship namely: self-confident, taskoriented and results, the courage to take risks,leadership, time-oriented front, and originality (Creativity and innovation).

The difference between social entrepreneurship and business entrepreneurship are [19]. a) Usually business entrepreneurs also take social responsibility actions; for example, employing people with physical or mental disabilities, the poor or people with certain social problems, b) A measure of the success of business entrepreneurship is financial performance (company value, profits for shareholders/owners), while a measure of the success of social entrepreneurship is financial and social results [20]. Social entrepreneurship functions as an agent of social change [21].

\section{METHODS}

The research method used was a classroom action research method by adapting Kemmis and Taggart's model. The research method consisted of several cycles. It used a teacher-centered by using project-based learning model. Teachers were expected to improve learning outcomes by choosing the right learning model [22]. Students were given the task to observe several socially sound businesses around them and compare them with profit-oriented businesses. It was conducted in the odd semester of the 2018/2019 academic year. The research subjects consisted of 40 students in the fifth semester of the Social Science Program. In addition, data analysis was performed by using quantitative descriptive analysis; i.e., analysis based on the results of data processing. 


\section{RESULTS AND DISCUSSION}

The classroom action research was carried out in the sociopreneuship class discussing about the topic of social entrepreneurship. The character values developed were creativity, innovative capabilities, willingness to take risks, good business ethics also norms, responsibility and self-discipline It took place in two cycles. The first cycle was held in two meetings discussing about the nature of entrepreneurship and social entrepreneurship. Students were assigned to groups in this cycle. The second cycle was carried out in three meetings discussing about theoretical studies and doing field studies by visiting a leather-waste crafts business applying the principles of social entrepreneurship (sociopreneurship) in Sukaregang, Garut. Leather jacket production waste was turned into useful items such as gloves, flower pots, and bags, but they needed limited marketing power and capabilities. Not only was he quality of human resources in the field of knowledge and skills, but it was also a tough mental attitude one effort currently made by educational institutions through education Entrepreneurship. Therefore, it was expected to be able to introduce to grow the soul entrepreneurship among students [5].

A business must use and apply good strategy in marketing management, be able to choose the appropriate market, and determine the appropriate marketing budget to be sustainable [23]. The class was carried out using a project-based method wherein the student groups had to make a social project to address social needs [24]. a) There were 40 students attending social lectures that integrated character education in the topic of social entrepreneurship, consisting of 15 men $(37.5 \%)$ and 25 women $(62.5 \%)$. b) The descriptive analysis involved five data used to measure the indicators of character values including creativity, innovative ability, willingness to take risks, good business ethics and norms, and responsibility and self-discipline.

The classification of each variable indicator was calculated using the following steps [25].: The highest score for each indicator of creativity was in : $40 \times 4=160$ while the lowest score for each infrastructure management indicator was in : $40 \times 1=40 . \mathrm{N}=$ highest value - lowest value, and $Z$ criteria: $160-40 / 4=30$. In addition, the classification was in interval: $40-70$ means low, 71-101 moderate, 102 - 132 means moderate, and 133 - 160 means high based on table 1 .

\subsection{Creativity}

Table 1. Creativity

\begin{tabular}{|c|l|l|l|l|}
\hline Response & Score & Frequency & $\begin{array}{c}\text { Total } \\
\text { Score }\end{array}$ & Percentage \\
\hline High & 4 & 0 & 0 & 0 \\
\hline Moderate & 3 & 12 & 36 & 42.9 \\
\hline
\end{tabular}

\begin{tabular}{|c|l|l|l|l|}
\hline $\begin{array}{c}\text { Fairly } \\
\text { moderate }\end{array}$ & 2 & 20 & 40 & 47.6 \\
\hline Low & 1 & 8 & 8 & 9.5 \\
\hline & & 40 & 84 & 100 \\
\hline
\end{tabular}

Table 1 showed that as many as $47.6 \%$ students demonstrated fairly-moderate creativity in doing a sociopreneurship project.

\subsection{Innovative Capabilities}

Table 2. Innovative Ability

\begin{tabular}{|c|l|l|l|l|}
\hline Response & Score & Frequency & $\begin{array}{c}\text { Total } \\
\text { Score }\end{array}$ & Percentage \\
\hline High & 4 & 3 & 12 & 11,21 \\
\hline Moderate & 3 & 26 & 78 & 72.9 \\
\hline $\begin{array}{c}\text { Fairly } \\
\text { moderate }\end{array}$ & 2 & 7 & 14 & 13 \\
\hline Low & 1 & 3 & 3 & 2.8 \\
\hline & & 40 & 107 & 100 \\
\hline
\end{tabular}

Table 2 showed that most students $(72.9 \%)$ were moderately innovative to do a sociopreneurship project.

\subsection{Willingness to Take Risks}

Table 3Willingness to Take Risks

\begin{tabular}{|c|l|l|l|l|}
\hline Response & Score & Frequency & $\begin{array}{c}\text { Total } \\
\text { Score }\end{array}$ & Percentage \\
\hline High & 4 & 3 & 12 & 10.61 \\
\hline Moderate & 3 & 29 & 87 & 77 \\
\hline $\begin{array}{c}\text { Fairly } \\
\text { moderate }\end{array}$ & 2 & 6 & 12 & 10.62 \\
\hline Low & 1 & 2 & 2 & 1.77 \\
\hline & & 40 & 113 & 100 \\
\hline
\end{tabular}

Table 3 showed that most students (77\%) were willing enough to take risks in doing a sociopreneurship project.

\subsection{Good Business Ethics and Norms}

Table 4. Good business ethics and norms

\begin{tabular}{|c|l|l|l|l|}
\hline Response & Score & Frequency & $\begin{array}{c}\text { Total } \\
\text { Score }\end{array}$ & Percentage \\
\hline High & 4 & 10 & 40 & 31.5 \\
\hline Moderate & 3 & 27 & 81 & 63.9 \\
\hline $\begin{array}{c}\text { Fairly } \\
\text { moderate }\end{array}$ & 2 & 3 & 6 & 4.71 \\
\hline Low & 1 & 0 & 0 & 0 \\
\hline & & 40 & 127 & 100 \\
\hline
\end{tabular}

Table 4 showed that most students (63.9\%) demonstrated moderately good business ethics and norms.

\subsection{Responsibility and Self-Discipline}

Table 5. Responsibility and self-discipline

\begin{tabular}{|l|l|l|l|l|}
\hline Response & Score & Frequency & $\begin{array}{c}\text { Total } \\
\text { Score }\end{array}$ & Percentage \\
\hline High & 4 & 5 & 20 & 18.18 \\
\hline Moderate & 3 & 25 & 75 & 68.18 \\
\hline
\end{tabular}




\begin{tabular}{|l|l|l|l|l|}
\hline $\begin{array}{l}\text { Fairly } \\
\text { moderate }\end{array}$ & 2 & 5 & 10 & 9.1 \\
\hline Low & 1 & 5 & 5 & 4.54 \\
\hline & & 40 & 110 & 100 \\
\hline
\end{tabular}

Table 5 showed that $68.18 \%$ of students demonstrated moderate responsibility

\section{CONCLUSIONS}

Social entrepreneurship is a form of entrepreneurship that aims to help society. Social business can be a form of social entrepreneurship, but not all social entrepreneurs are in the form of social business. It is an innovative (economic or non-economic, profit or nonprofit) initiative. The results of the research showed that sociopreneurship learning can foster an entrepreneurial spirit in the students majoring in social science education at Institut Pendidikan Indonesia Garut, so that important basic entrepreneurship values which covered in creativity, innovative ability, willingness to take risks, good business ethics and norms, and responsibility and self-discipline are established within every individual. The increasing is included in the medium category.

\section{REFERENCES}

[1] M. Masturin, "Model pemberdayaanmasyarakat dengan pendekatan social entrepreneurship: Analisis Ketokohan Para Pewirausaha Sosial," INFERENSI, 2005, doi: 10.18326/infsl3.v9i1.159182.

[2] Agustiyanti, "Pengangguran bertambah jadi 7,05 juta orang per agustus, tertinggi smk artikel ini telah tayang di katadata.co.id dengan judul 'pengangguran bertambah jadi 7,05 juta orang per agustus, tertinggi smk', https://katadata.co.id/agustiyanti/finansial/5e9a4e5 5," katadata.co.id, Nov. 05, 2019. https://katadata.co.id/agustiyanti/finansial/5e9a4e5 58c461/pengangguran-bertambah-jadi-705-jutaorang-per-agustus-tertinggi-smk (accessed Sep. 05, 2019).

[3] BPS.go.id, "The indonesian statistcs recorded that the number of university graduates working," BPS.go.id, 2019. .

[4] Kompasiana, "DEA 2017 wujudkan wirausaha berkelanjutan," www.kompasiana.com, 2017. https://www.kompasiana.com/www.stevanmanihuruk.com/59e164d357c78c208162ce22/dea2017-wujudkan-wirausaha-berkelanjutan?page $=\mathrm{al}$ (accessed Sep. 10, 2019).

[5] Eriawaty dan Fitriyanti, "Peran mata kuliah kewirausahaan dalam menumbuhkan jiwa wirausaha mahasiswa pendidikan ekonomi," $J$. Profit, 2016.
[6] A. Taufik and Akmal, "Peran mata kuliah kewirausahaan dalam menumbuh- kembangkan jiwa enterpreneur mahasiswa ppkn," JCE J. Civ. Educ., vol. 1, no. 4, pp. 343-349, 2018.

[7] Tetep, "The role of socio-economic background, family economic education and financial literacy on student decision making," in Proceedings of the 4th Global Conference on Business Management \& Entrepreneurship (GC-BME 4), 8 August 2019, Bandung, Indonesia., 2020, p. 550, doi: 9780367674717.

[8] L. lak N. Hasanah, "Pengembangan kewirausahaan sosial pada perguruan tinggi melalui social project competition," J. Stud. Pemuda, vol. 7, no. 2, p. 90 , 2019, doi: 10.22146/studipemudaugm.40210.

[9] A. Suherman, “Analisis penganggaran pendidikan dan keterampilan komunikasi kepala sekolah terhadap kepuasan kerja guru smkn kabupaten ciamis," J. Ilm. Edukasi, pp. 335-342, 2018.

[10] P. S. Prasetyo, T. Gunawan, T. Rachmawati, and T. S. Herwanto, "Inovasi untuk mewujudkan desa unggul dan berkelanjutan," 2017, [Online]. Available:

http://repository.unpar.ac.id/bitstream/handle/1234 56789/5722/Pius_143180 \%28Ed.2\%29p.pdf? sequence $=4 \&$ is Allowed $=y$.

[11] I. P. Sofia, "Konstruksi model kewirausahaan sosial (social entrepreneurship) sebagai gagasan inovasi sosial bagi pembangunan perekonomian," Widyakala J., vol. 2, no. 1, p. 2, 2017, doi: 10.36262/widyakala.v2i1.7.

[12] W.-L. Tan, J. Williams, and T.-M. Tan, "Defining the 'sosial' in 'sosial entrepreneurship': altruism and entrepreneurship," Int. Entrep. Manag. J., pp. 353-365, 2005.

[13] T. Widyanti, Tetep, and E. Mulyana, "Analisis faktor pendidikan dan demografi terhadap tingkat literasi ekonomi mahasiswa," Bus. Innov. Entrep. J., vol. 1, no. 3, pp. 203-209, 2019.

[14]H. Suyatna and Y. Nurhasanah, "Sociopreneurship sebagai tren karir anak muda," J. Stud. Pemuda, vol. 6, no. 1, p. 527, 2018, doi: 10.22146/studipemudaugm.38011.

[15]S. D. Appanah and B. Estin, "Social entreprenuership definition matrix'," 2009. www.changefusion.com (accessed Sep. 05, 2019).

[16]D. R. Rahadi and E. Susilowaty, "Kreatifitas kewirausahaan sosial dan menggali ide usaha baru melalui pengolahan kripik tempe lupin," $J$. Pengabdi. Kewirausahaan, vol. 1, no. 1, pp. 17-24, 2014. 
[17] L. Hulgård, "Discourses of social entrepreneurshipvariations of the same theme?," EMES Eur. Res. Netw., 2010.

[18] G. G. Meredith, Kewirausahaan: teori dan praktek. Jakarta: PPM, 2002.

[19] J. Boschee and J. McClurg, "Towards a better understanding of christian social entrepreneurship," p. 364, 2003.

[20]U. K. Yaumidin, "Kewirausahaan sosial dan tanggung jawab sosial perusahaan: tantangan sinergi multi-sektor dan multi-dimensi," J. Ekon. dan Pembang., vol. 21, no. 1, pp. 103-123, 2013.

[21]P. E. J. Gregory Dees, Jed Emerson, Enterprising nonprofits: a toolkit for social entrepreneurs. John Wiley \& Sons, 2001.

[22] Y. Susanti, A. Suherman, and A. Fauzi, "Model pembelajaran arias dengan seting kooperatif tipe jigsaw terhadap hasil belajar," J. Civ. Soc. Stud., vol. 3, no. 2, pp. 60-67, 2020, doi: 10.31980/26557304.v3i2.698.

[23][T. Tetep and A. Suherman, "Analisis akuntansi pertanggungjawaban dalam penentuan anggaran biaya pemasaran," Bus. Innov. Entrep. J., vol. 1, no. 1, pp. 1-4, 2019, doi: 10.35899/biej.v1i1.6.

[24] Penny Rahmawaty, D. H. Suwarto, and M. L. Endarwati, "Artikel hasil penelitian pengembangan metode pembelajaran pendidikan karakter melalui kewirausahaan sosial," Staf Pengajar Fak. Ekon. Univ. Negeri Yogyakarta, vol. 9, no. 1, pp. 76-99, 2018.

[25] Sugiyono, "Metode penelitian," Metod. Penelit., 2003.

[26] Hulgard , Lars (2010). Discourses of social entrepreneurship -variation of the same theme? EMES European Research Network. 